\title{
Relationship of ABO and Rh blood groups with history of gastritis in the undergraduate medical and dental students: a cross-sectional study
}

\author{
Nilu Manandhar ${ }^{1}$, Kushal Bhattarai ${ }^{2}$ \\ ${ }^{1}$ Department of Physiology, ${ }^{2}$ Department of Biochemistry College of Medical Sciences and Teaching \\ Hospital, Bharatpur, Chitwan, Nepal
}

\section{Correspondence}

Dr. Nilu Manandhar

Department of Physiology

College of Medical Sciences

and Teaching Hospital

Bharatpur, Chitwan, Nepal

Email:

menilu4@gmail.com

DOI: http://dx.doi.org/10.3126/ jemsn.v13i4.18479

Orcid ID: orcid.org/0000-0002 $-5410-8805$

Article received: Oct $24^{\text {th }} 2017$ Article accepted: Dec $7^{\text {th }} 2017$

\begin{abstract}
Background \& Objectives: The various $\mathrm{ABO}$ and $\mathrm{Rh}$ blood groups with different distribution frequencies in the general population have been found to be associated with different diseases, most notably gastritis. Many studies have claimed $\mathrm{Rh}$ groups to be indifferent to such association. Nonetheless, ABO group is found to linked with chronic gastritis. The aim of this study was to estimate the frequencies of $A B O$ and Rh blood groups and the gastritis amongst the first and second year undergraduate medical and dental students; and to study their relationships. Materials \& Methods: In a descriptive, cross-sectional study, 247 study participants were enrolled. After procuring clearance from the institutional review committee and the informed and written consent from the study participants, data collection was done on the variables, year of study (first or second year), gender, blood groups (ABO and Rh) and history of gastritis (present or absent). Results: Blood group $\mathrm{O}$ was the commonest $(\mathrm{n}=99 ; 40.1 \%)$ followed by group $\mathrm{B}(\mathrm{n}=77$; $31.2 \%)$. Similarly, 239 (96.8\%) participants were Rh-positive as compared to $8(3.2 \%) \mathrm{Rh}$-negative. Interestingly, $46(18.6 \%)$ of the participants reported positive history of gastritis. Participants with blood group $\mathrm{O}$ had the greatest odds $(\mathrm{OR}=1.64)$ of having history of gastritis compared with those with other blood groups combined. Distribution of study participants based on gender and history of gastritis in either systems of blood grouping shoed no significant difference in their proportions $(p>0.05)$. Conclusion: In light of the above findings, further longitudinal studies can be designed to better asses the relationship.
\end{abstract}

Key words: Blood groups; ABO groups, Rh groups; gastritis

Citation: Manandhar N, Bhattarai K. Relationship of $\mathrm{ABO}$ and $\mathrm{Rh}$ blood groups with history of gastritis in the undergraduate medical and dental students: a cross-sectional study. JCMS Nepal. 2017;13(4):372-7.

\section{INTRODUCTION}

Blood group antigens, $\mathrm{A}, \mathrm{B}$, and $\mathrm{D}$ present on the membrane of red blood cells account for the ABO and $\mathrm{Rh}$ blood group systems, respectively. ${ }^{1}$ These antigens are permanent, fixed and lifelong biological markers of any individual, as unique as fingerprints. ${ }^{2,3}$ In $\mathrm{ABO}$ system, blood group $\mathrm{A}$ contains $\mathrm{A}$-antigen and anti-B-antibody; group $\mathrm{B}$ contains $\mathrm{B}$-antigen and anti-B-antibody; $\mathrm{AB}$ contains both A- and B-antigens and no antibodies whereas $\mathrm{O}$ blood group contains no antigens and both anti-A and anti-B antibodies. In this system, all blood groups have H-antigen, a complex oligosaccharide with a terminal fucose. Group A has terminal $\mathrm{N}$-acetylgalactosamine on $\mathrm{H}$-antigen; $\mathrm{B}$ has terminal galactose and whereas blood group $\mathrm{AB}$ has both, $\mathrm{O}$ group has neither apart from the $\mathrm{H}$-antigen. In $\mathrm{Rh}$ system, the most antigenic $\mathrm{D}$ is the characteristic antigen. ${ }^{1}$

The distribution of the $\mathrm{ABO}$ blood groups varies in populations throughout the world. ${ }^{4}$ In well documented studies, O blood group has been found to have a frequency of about $45 \%$, A-group about $41 \%$, whereas B is $10 \%$ and $\mathrm{Ab}$ only $4 \%$. Similarly, in the Asian population, it has been found that more than $99 \%$ are D-positive, in addition to prevalence of 
ABO blood groups as (A: 25\%; B: 25\%; AB: $5 \%$ and O: $45 \%)^{1}$

Apart from the associated clinical significance in transfusion, it is becoming increasingly apparent that $\mathrm{ABO}$ antigens are of biological significance and may be associated with predisposition to, or protection from many diseases. ${ }^{2}$ Evidence from several studies suggests that the individuals with various blood groups (as per the $\mathrm{ABO}$ and $\mathrm{Rh}$ systems) are differently susceptible to certain diseases. ${ }^{1}$

Many studies have rightly reported the higher prevalences of gastric ailments like gastric and duodenal ulcers in individuals with blood group $\mathrm{O}$. Although many such evidences fail to back up the association with sufficient explanations, it has been a common notion amongst them that increased colonization of the gastric and duodenal mucosal cells of group $\mathrm{O}$ subjects with $\mathrm{H}$. pylori, the most significant infectious agent for such conditions, accounts for such observations. Nonetheless, many studies have found that individuals with blood group A have also been found to be at increased risk for the development of gastric carcinoma, $\mathrm{H}$. pylori being the possible link.

Undergraduate Medical and Dental students, unlike other professionals, are under relentless mental hassle to live up to their academic errands. Psychological stress, one of the significant risk factors for the development of gastric ailments like gastric and duodenal ulcers, cannot be unheeded in such individuals. Therefore, we conducted the present study to estimate the frequencies of blood groups ( $\mathrm{ABO}$ and $\mathrm{Rh}$ ) and the gastric problems amongst the first and second year undergraduate medical and dental students; and to study their relationships in these study participants.

\section{MATERIALS AND METHODS}

The study was conducted in the department of Physiology, College of Medical Sciences and Teaching Hospital from June 2017 to July 2017 after procuring permission from the institutional review committee (IRC). Using a descriptive, crosssectional design, data collection was done on variables, year of study, gender, blood groups ( $\mathrm{ABO}$ and $\mathrm{Rh}$ ) and history of gastritis in the study participants i.e., first and second year medical and dental students after obtaining written and informed consent. All the students willing to participate were included in the study. History of gastritis was assessed in the form of absence or presence (diagnosed or undiagnosed) of history of gastritis.
Blood groups (ABO and $\mathrm{Rh})$ of the participants were collected from their official records in the institution. Any participant without any record of the blood group or not willing to participate was excluded from the study. A total of 247 students were enrolled in the study as the study participants. Initial entry of the collected data was done in Microsoft Office EXCEL 2016 software. After refining, the data was finally analysed using Statistical Package for Social Science (SPSS) software version 16 . The different variables used in the study were categorical, i.e., year of study (first or second year), gender (male or female), ABO blood groups (A, $\mathrm{B}, \mathrm{AB}$ or $\mathrm{O}), \mathrm{Rh}$ blood groups (positive or negative) and history of gastritis (yes or no). Frequencies with percentages were used to represent the summary measures of the variables. To test the difference in the proportions of different relevant variables, chi-squared $(\chi 2)$ test was used. Additionally, odds ratio (OR) with $95 \%$ confidence interval (CI) was used to assess the relationship between the different blood groups and the presence of absence of the history of gastritis. The statistical significance was set at $\mathrm{p}<0.05$.

\section{RESULTS}

The total number of study participants initially considered in the study was 290 (140 from first year and 150 from second year). After excluding the students using the set criteria, a total of 247 were enrolled as the final study participants $(129 ; 52.2 \%$ from first year and $118 ; 47.8 \%$ from second year). Of the total 247 study participants, 146 (59.1\%) were male and 101 (40.9\%; female). Blood group O was the commonest one amongst the various $\mathrm{ABO}$ blood groups $(99 ; 40.1 \%)$ followed by group B (77; $31.2 \%)$. Similarly, 239 (96.8\%) students had Rhpositive blood groups as compared to $8(3.2 \%) \mathrm{Rh}$ negative. Interestingly, $46(18.6 \%)$ of the participants reported history of gastritis. (Table 1)

As depicted in table 2, blood group $\mathrm{O}$ was the most prevalent one in both $\mathrm{Rh}$ positive and negative individuals $(40.2 \%$ in $\mathrm{Rh}$ positive and $37.5 \%$ in $\mathrm{Rh}$ negative). The second prevalent group was group $\mathrm{B}$ in $\mathrm{Rh}$ positive and both group $\mathrm{A}$ and $\mathrm{B}$ in $\mathrm{Rh}$ negative individuals $(31.4 \%$ in $\mathrm{Rh}$ positive and $25.0 \%$ in $\mathrm{Rh}$ negative).

Table 3 illustrates the distribution of the participants with two systems of blood groups (ABO and $\mathrm{Rh}$ ), based on gender and history of gastritis. Blood group $\mathrm{O}$ was the most prevalent in both male and female students (40.4\%; males and 
Table 1: Frequency distribution of the study participants for the different categorical variables used in the study

\begin{tabular}{|lcc|}
\hline $\begin{array}{l}\text { Variable } \\
\text { Year of Study }\end{array}$ & Frequency & $\mathbf{\%}$ \\
\hline First Year & 129 & 52.2 \\
\hline $\begin{array}{l}\text { Second Year } \\
\text { Gender }\end{array}$ & 118 & 47.8 \\
\hline Male & 146 & 59.1 \\
\hline Female & 101 & 40.9 \\
\hline $\begin{array}{l}\text { Blood Group } \\
\text { (ABO) }\end{array}$ & & \\
\hline Group A & 48 & 19.4 \\
\hline Group B & 77 & 31.2 \\
\hline Group AB & 23 & 9.3 \\
\hline Group O & 99 & 40.1 \\
\hline
\end{tabular}

\section{Blood Group}

(Rh)

$\begin{array}{lcc}\text { Rh Positive } & 239 & 96.8 \\ \begin{array}{l}\text { Rh Negative } \\ \text { History of Gas- } \\ \text { tritis }\end{array} & 8 & 3.2 \\ \text { Yes } & 46 & 18.6 \\ \text { No } & 201 & 81.4\end{array}$

$39.6 \%$; females) followed by group B (30.8\%; males and $31.7 \%$; females). Similarly, most of them (both males and females) were Rh positive (96.6\%; males and 97\%; females). Gender-wise distribution of participants in either systems of blood group showed no significant difference between their proportions $(p>0.05 ; \chi 2$-Test). Next, the prevalence of positive history of gastritis was the maximum in participants with blood group O $(23.2 \%)$ followed by group A (20.8\%). Similarly, $25.0 \%$ of the Rh negative individuals reported such history. Distribution of participants based on history of gastritis in either system of blood groupings also showed no significant difference between their proportions ( $\mathrm{p}>0.05 ; \chi 2$-Test).

Finally, as depicted in table 4, participants with blood group "O" had the greatest odds (OR,1.64; 95\%CI, 0.86-3.13) i.e., 1.64 times greater odds of having history of gastritis compared with those with other blood groups combined. This was followed by the participants of "A" blood group (OR, 1.19; 95\% CI, 0.54-2.61). Similarly, table 4 also shows that individuals with $\mathrm{Rh}$ negative blood groups had 1.48 times greater odds of having history of gastritis as

Table 2: Frequency distribution of $\mathrm{ABO}$ blood groups in participants with $\mathrm{Rh}$ positive and negative groups

\begin{tabular}{lllll|}
\multicolumn{2}{c}{ Blood Group (ABO) } & & & \\
Blood Group (Rh) & Group A & Group B & Group AB & Group O \\
& 46 & 75 & 22 & 96 \\
Rh Positive & $(95.8 \%)^{\mathrm{a}}(19.2 \%)^{\mathrm{b}}$ & $(97.4 \%)^{\mathrm{a}}(31.4 \%)^{\mathrm{b}}$ & $(95.7 \%)^{\mathrm{a}}(9.2 \%)^{\mathrm{b}}$ & $(97.0 \%)^{\mathrm{a}}(40.2 \%)^{\mathrm{b}}$ \\
\hline & 2 & 2 & 1 & 3 \\
Rh Negative & $(4.2 \%)^{\mathrm{a}}(25.0 \%)^{\mathrm{b}}$ & $(2.6 \%)^{\mathrm{a}}(25.0 \%)^{\mathrm{b}}$ & $(4.3 \%)^{\mathrm{a}}(12.5 \%)^{\mathrm{b}}$ & $(3.0 \%)^{\mathrm{a}}(37.5 \%)^{\mathrm{b}}$
\end{tabular}

a: Occurrence (percentage) along a column

b: Occurrence (Percentage) along a row

Table 3: Frequency distribution of $\mathrm{ABO}$ blood groups according to gender and history of gastritis

\begin{tabular}{|c|c|c|c|c|c|c|}
\hline \multirow[b]{2}{*}{ Variable } & \multicolumn{4}{|c|}{ Blood Group (ABO) } & \multicolumn{2}{|c|}{ Blood Group (Rh) } \\
\hline & Group A & Group B & $\begin{array}{c}\text { Group } \\
\text { AB }\end{array}$ & $\begin{array}{c}\text { Group } \\
\text { O }\end{array}$ & $\mathbf{R h}(+)$ & $\mathbf{R h}(-)$ \\
\hline Gender & \multicolumn{6}{|c|}{ Prevalence (\%) across the total of rows } \\
\hline Male $(n=146)$ & $\begin{array}{c}28 \\
(19.2 \%)\end{array}$ & $\begin{array}{c}45 \\
(30.8 \%)\end{array}$ & $\begin{array}{c}14 \\
(9.6 \%)\end{array}$ & $\begin{array}{c}59 \\
(40.4 \%)\end{array}$ & $\begin{array}{c}141 \\
(96.6 \%)\end{array}$ & $\begin{array}{c}5 \\
(3.4 \%)\end{array}$ \\
\hline Female $(n=101)$ & $\begin{array}{c}20 \\
(19.8 \%)\end{array}$ & $\begin{array}{c}32 \\
(31.7 \%)\end{array}$ & $\begin{array}{c}9 \\
(8.9 \%)\end{array}$ & $\begin{array}{c}40 \\
(39.6 \%)\end{array}$ & $\begin{array}{c}98 \\
(97.0 \%)\end{array}$ & $\begin{array}{c}3 \\
(3.0 \%)\end{array}$ \\
\hline Significance (p) & \multicolumn{4}{|c|}{$\mathrm{p}=0.996\left(\chi^{2}-\right.$ Test $)$} & \multicolumn{2}{|c|}{$\mathrm{p}=0.843\left(\chi^{2}\right.$-Test $)$} \\
\hline History of Gastritis & \multicolumn{6}{|c|}{ Prevalence (\%) across the total of columns } \\
\hline Yes $(n=46)$ & $\begin{array}{c}10 \\
(20.8 \%)\end{array}$ & $\begin{array}{c}10 \\
(13.0 \%)\end{array}$ & $\begin{array}{c}3 \\
(13.0 \%)\end{array}$ & $\begin{array}{c}23 \\
(23.2 \%)\end{array}$ & $\begin{array}{c}44 \\
(18.4 \%)\end{array}$ & $\begin{array}{c}2 \\
(25.0 \%)\end{array}$ \\
\hline No $(n=201)$ & $\begin{array}{c}38 \\
(79.2 \%)\end{array}$ & $\begin{array}{c}67 \\
(87.0 \%)\end{array}$ & $\begin{array}{c}20 \\
(87.0 \%)\end{array}$ & $\begin{array}{c}76 \\
(76.8 \%)\end{array}$ & $\begin{array}{c}195 \\
(81.6 \%)\end{array}$ & $\begin{array}{c}6 \\
(75.0 \%)\end{array}$ \\
\hline Significance (p) & \multicolumn{4}{|c|}{$\mathrm{p}=0.304\left(\chi^{2}\right.$-Test $)$} & \multicolumn{2}{|c|}{$\mathrm{p}=0.181\left(\chi^{2}\right.$-Test $)$} \\
\hline
\end{tabular}




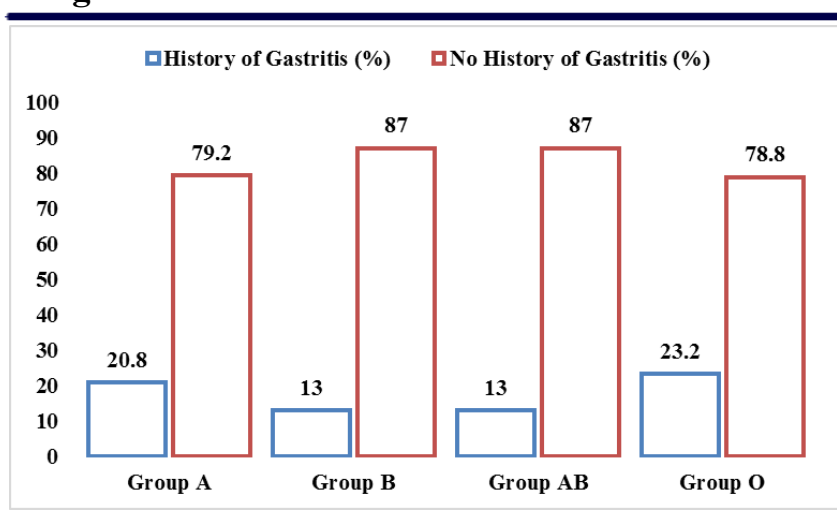

Figure 1: Distribution of participants based on history of gastritis (\%) and different $\mathrm{ABO}$ blood groups

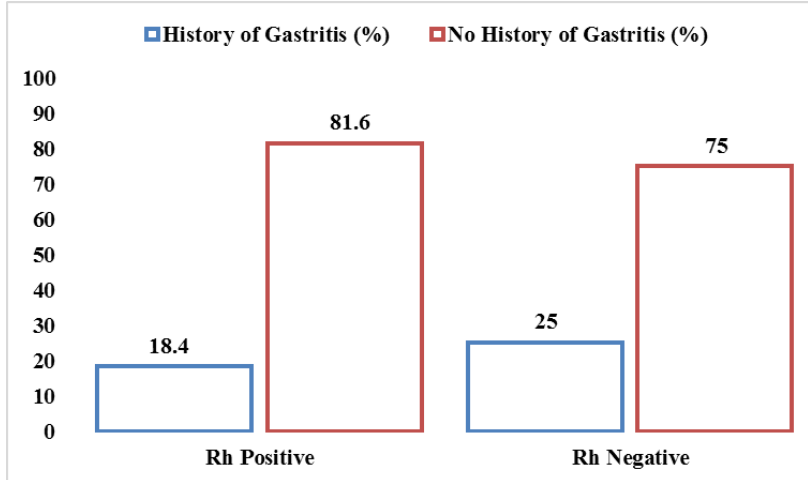

Figure 2: Distribution of participants based on history of gastritis (\%) and two Rh blood groups

\section{DISCUSSION}

The two major systems of blood groups, i.e., ABO and $\mathrm{Rh}$ systems are uniquely related to many diseases, most importantly the gastritis. Differences in the prevalences of the different groups under each system in the population and their susceptibility to the gastric problems prompted us to conduct our study in first and second year medical and dental students.

In our study, we recruited 247 students as the study participants $(129 ; 52.2 \%$ from first year and 118 ; $47.8 \%$ from the second year). Of them, $59.1 \%$ $(n=146)$ were male and $40.9 \% \quad(n=101)$ were female. Amongst the various ABO blood groups, maximum participants had blood group $\mathrm{O}(\mathrm{n}=99$; $40.1 \%)$, followed by group B $(\mathrm{n}=77 ; 31.2 \%)$. Likewise, 239 (96.8\%) students had Rh-positive blood groups as compared to $8(3.2 \%) \mathrm{Rh}$-negative. (Table 1) Blood group $\mathrm{O}$ was the most prevalent one in both $\mathrm{Rh}$ positive and negative individuals (40.2\%; Rh positive and 37.5\%; Rh negative). This was followed by blood group $\mathrm{B}$ in $\mathrm{Rh}$ positive (31.4\%) and both groups A and B in Rh negative individuals (25.0\%) (Table 2). Blood group $\mathrm{O}$ was the most prevalent in both male and female students (40.4\%; males and 39.6\%; females) followed by group B (30.8\%; males and 31.7\%; females). Similarly, most of them (both males and females) were Rh positive (96.6\%; males and $97 \%$; females). Gender-wise distribution of participants in either systems of blood group showed no significant difference between their proportions $\left(\mathrm{p}>0.05 ; \chi^{2-}\right.$ Test), (Table 3).

A remarkable $18.6 \%(n=46)$ of the participants recounted the history of gastritis. (Table 1). Next, the prevalence of positive history of gastritis was the maximum in participants with blood group $\mathrm{O}$ (23.2\%) followed by group A (20.8\%). Similarly, $25.0 \%$ of the $\mathrm{Rh}$ negative individuals reported such history. Distribution of participants based on history of gastritis also showed no significant difference between their proportions $(p>0.05 ; \chi 2$ Test), (Table 3). Participants with blood group "O" had the greatest odds (OR, $1.64 ; 95 \% \mathrm{CI}, 0.86-3.13)$ i.e., 1.64 times greater odds of having history of gastritis compared to those with other blood groups combined. This was followed by the participants of "A" blood group (OR, 1.19; 95\% CI, 0.54-2.61). Similarly, individuals with $\mathrm{Rh}$ negative blood groups had 1.48 times greater odds of having history of gastritis as compared to those with Rh positive group, (Table 4).

Plethora of studies have demonstrated that

Table 4: ABO and Rh blood groups and history of gastritis; odds ratios with $95 \% \mathrm{CI}$

\begin{tabular}{|cccccc|}
\hline Blood Group & Total & \multicolumn{2}{c}{ History of Gastritis } & \multicolumn{2}{c|}{ Odds Ratio (OR) } \\
& & Yes & No & OR & $\mathbf{9 5 \%}$ CI \\
\hline ABO System & 247 & & & & \\
\hline Group A & 48 & 10 & 38 & 1.19 & $0.54-2.61$ \\
Group B & 77 & 10 & 67 & 0.56 & $0.26-1.19$ \\
\hline Group AB & 23 & 3 & 20 & 0.63 & $0.18-2.22$ \\
\hline Group O & 99 & 23 & 76 & 1.64 & $0.86-3.13$ \\
\hline Rh System & 247 & & & & \\
\hline Rh Positive & 239 & 44 & 195 & 0.68 & $0.13-3.47$ \\
\hline Rh Negative & 8 & 2 & 6 & 1.48 & $0.29-7.57$ \\
\hline
\end{tabular}


individuals with blood group $\mathrm{O}$ have a higher risk of developing duodenal ulcers and also a higher incidence of gastric ulcers. ${ }^{5}$ In separate studies, the ABO phenotype has been linked with stomach ulcers, which are more common in individuals with blood group $\mathrm{O}^{6}$

Many authors report an association between blood group $\mathrm{O}$ and $\mathrm{H}$. pylori infection.7-10 Epidemiological studies have reported increased frequency of peptic (gastric and duodenal) ulcers in population with blood group $\mathrm{O}$, with higher density of colonization of $\mathrm{H}$. pylori onto the epithelial cells of subjects with this group. ${ }^{8,11-13}$ It has been demonstrated that the epithelial cells of persons of group $\mathrm{O}$ bound significantly more $\mathrm{H}$. pylori than did cells of persons of other blood groups. ${ }^{7,8}$

Similarly, the increased susceptibility to peptic ulceration among persons with blood group $\mathrm{O}$ was due to density of colonization of epithelial cells and higher inflammatory responses to $\mathrm{H}$. pylori. ${ }^{13} \mathrm{H}$. pylori expresses lipopolysaccharides on its outer membrane including blood group antigen-binding adhesion A (BabA adhesion) which causes adhesion of bacteria to gastric epithelium and allow persistent colonization ${ }^{14}$ Additionally, the study by Petrovic et al., ${ }^{15}$ has shown that the presence of $\mathrm{H}$. pylori did not relate to $\mathrm{Rh}$ factor.

Notwithstanding, many studies have failed to find an association between $\mathrm{ABO}$ blood groups and peptic ulcer disease. Many other studies have also failed to find any association between blood group and $\mathrm{H}$ pylori infection. ${ }^{16-18}$ Still other studies have also demonstrated that the $\mathrm{O}$ blood group did not represent a risk factor for $\mathrm{H}$. pylori infection. ${ }^{19,20}$

The apparent inadequacy of the present study is the small number of study participants and the inclusion of students (of a particular age group) only. The result obtained can be better generalized if large number of participants with varied age groups are taken. Moreover, in our study, we had to rely on students' recall of the history of gastric problems which could have been misleading many a times. This could have been better supplemented with an examination of the participants to elicit the status of their gastric problems. The ABO and Rh blood groups of the participants were collected from their official records; reliance on such source could be a source of error. Additionally, important serological and other biomarkers of $\mathrm{H}$. pylori infection were not used in our study to characterize the infection. Finally, the descriptive cross-sectional design of the study could have been replaced with a longitudinal study to better elicit the causal relationships between the variables of interest in the study.

Despite many shortcomings, the findings in our study were in agreement with many other similar studies that clearly accounts for its generalisability. As such, the findings of our study provided considerable scope for performing further studies to elucidate the association more clearly. Lastly, the study participants were the first and second year. Hence, there was lesser chance of other important causes of gastritis to have already set in; in addition to the obvious benefit the students can gain from such study findings to bring about modification in their personal lifestyles.

\section{CONCLUSION}

In light of the findings suggesting the highest frequency of the history of gastritis in participants with blood group $\mathrm{O}$, further longitudinal studies can be planned to better assess the relationship between blood groups and gastric problems.

\section{REFERENCES}

1. Barret KE, Barman SM, Boitano S, Brooks HL. Ganong's review of medical physiology. 24th ed. New York: Mc Graw Hill; 2012.

2. Ravn ME, Bird GW. Associations between human red cell blood group antigens and diseases. Transfusion Medicine Reviews 1990;4(1):47-55. https://doi.org/10.1016/S08877963(90)70247-7.

3. Gaidaa KB, Amin Al-Suami, Saad SH. Relationship between $\mathrm{ABO}$ blood groups and Helicobacter pylori infection among patients with dyspepsia. Journal of Virology and Microbiology 2016:1-9. https:// doi.org/10.5171/2016.688370.

4. Garratty G, Glynn SA, McEntire R. ABO and Rh(D) phenotype frequencies of different racial/ethnic groups in the United States. Transfusion 2004;44(5):703-6. https:// doi.org/10.1111/j.1537-2995.2004.03338.x.

5. Martins LC, Covelo TCO, Oti HT, Loiola RSP, Anguiar $\mathrm{DC}$, Barile KAS, et al. $\mathrm{ABH}$ and Lewis antigen distributions in blood, saliva and gastric mucosa and $\mathrm{H}$. pylori infection in gastric ulcer patients. World Journal of Gastroenterology 2006;12(7):1120-4. https:// doi.org/10.3748/wjg.v12.i7.1120.

6. Iodice S, Maisonneuve P, Botteri E, Sandri MT, Lowenfels AB. ABO blood group and cancer. European Journal of Cancer 2010;46(18):3345-50. https://doi.org/10.1016/ j.ejca.2010.08.009. PMID: 20833034.

7. Kanbay M, Gur G, Arslan H, Yilmaz U, Boyaciouglu S. The relationship of $\mathrm{ABO}$ blood group, age, gender, smoking and Helicobacter pylori infection. Digestive Disease and Sciences 2005;50(7):1214-7. https:// doi.org/10.1007/s10620-005-2762-y.

8. Alkout AM, Blackwell CC, Weir DM, Poxton IR, Elton RA, Luman W, et al. Isolation of a cell surface component of Helicobacter pylori that binds $\mathrm{H}$ type 2, Lewis(a), and Lewis(b) antigens. Gastroenterology 1997;112(4):1179-87. https://doi.org/10.1016/s0016-5085(97)70129-x.

9. Lin CW, Chang YS, Wu SC, Cheng KS. Helicobacter pylori in gastric biopsies of Taiwanese patients with gastroduodenal diseases. Japanese Journal of Medical 
Science and Biology 1998;51(1):13-23. https:// doi.org/10.7883/yoken1952.51.13.

10. Henriksson K, Uribe A, Sandstedt B, Nord CE. Helicobacter pylori infection, $\mathrm{ABO}$ blood group, and effect of misoprostol on gastroduodenal mucosa in NSAIDtreated patients with rheumatoid arthritis. Digestive Diseases and Sciences 1993;38(9):1688-96. https:// doi.org/10.1007/bf01303179.

11. Clark CA, Wyn Edward J, Haddock DRW, Howel-Evans AW, McConnell RB, Sheppard PM. ABO blood groups and secretor character in duodenal ulcer. BMJ 1956;2 (4995):725-31. https://doi.org/10.1136/bmj.2.4995.725.

12. Mentis A, Blackwell CC, Weir DM, Spilialdis C, Dailianas A, Skandalis N. ABO blood group, secretor status and detection of Helicobacter pylori among patients with gastric or duodenal ulcers. Epidemiology and Infection 1991;106(2):221-9. https://doi.org/10.1017/ s0950268800048366. PMID:2019293

13. Alkout AM, Blackwell CC, Weir DM. Increased inflammatory responses of persons of blood group $\mathrm{O}$ to Helicobacter pylori. Journal of Infectious Disease 2000;181 (4):1364-9. https://doi.org/10.1086/315375.

14. Linde NS, Nordman H, Hedenbro J, Hurting H, Bore NT, Carlsted I. Strain- and blood group-dependent binding of Helicobacter pylori to human gastric MUC5AC glycoforms. Gastroenterology 2002;123(6):1923-30. https://doi.org/10.1053/gast.2002.37076.

15. Petrovic M, Artiko V, Novosel S, Ille T. Relationship between Helicobacter pylori infection estimated by 14Curea breath test and gender, blood groups and Rhesus factor. Hellenic Journal of Nuclear Medicine 2011;14(1):21 -4. PMID: 21512660.

16. Dickey W, Collins JSA, Watson RGP, Sloan JM, Porter KG. Secretor status and Helicobacter pylori infection are independent risk factors for gastroduodenal disease. Gut 1993;34(3):351-3. $\quad$ https://doi.org/doi.org/10.1136/ gut.34.3.351.

17. Evans DG, Graham DY, Klein PD. A sensitive and specific serologic test for detection of Campylobacter pylori infection. Gastroenterology 1989;96(4):1004-8. https:// doi.org/10.1016/0016-5085(89)91616-8.

18. Jaff MS. Relation between $\mathrm{ABO}$ blood groups and Helicobacter pylori infection in symptomatic patients. Clinical and Experimental Gastroenterology 2011;4:221-6. https://doi.org/10.2147/CEG.S23019. PMID:22016583.

19. Seyda T, Derya C, Fusun A, Meliha K. The relationship of Helicobacter pylori positivity with age, sex, and $\mathrm{ABO} /$ Rhesus blood groups in patients with gastrointestinal complaints in Turkey. Helicobacter 2007;12(3):244-50. https://doi.org/10.1111/j.1523-5378.2007.00500.x.

20. Sharara A, Abdul-Baki H, El Hajj L, Kreidielh N, Kfoury Baz EM. Association of gastrointestinal disease phenotype with $\mathrm{ABO}$ blood group and Helicobacter pylori virulencespecific serotypes. Digestive and Liver Diseases 2006;38 (11):829-33. https://doi.org/10.1016/j.dld.2006.06.040. 